\title{
Miocene collision-related conglomerates near Dazhuqu and Xigaze, Yarlung Tsangpo suture zone, Tibet
}

\author{
Angel On Kee Chan†*, J onathan C Aitchison†, Badengzhuł and Lan Hui† \\ † Tibet Reseach Group, Department of Earth Sciences, James Lee Bldg., University of Hong Kong, Pokfulam Road, Hong Kong SAR, \\ CHINA \\ ¥ Geological Team No. 2, Tibet Geological Survey, Lhasa, Tibet, CHINA \\ * To whom correspondence should be addressed.E-mail: chanangel@hkusua.hku.hk
}

The conglomeratic Dazhuqu and Qiuwu formations are correlative units associated with the Gangrinboche facies of southern Tibet. Rocks of this facies crop out for $>2000 \mathrm{~km}$ along the strike of Yarlung Tsangpo suture zone from west of Mt Kailas $\left(81^{\circ} \mathrm{E}\right)$ to east of Namche Barwa $\left(95^{\circ} \mathrm{E}\right)$. As these predominantly coarse clastic rocks record tectonic activity associated with the collision between India and Eurasia their detailed study should further clarify our understanding of this event.

Dazhuqu and Qiuwu are the local names used in mapping near the towns of Xigaze and Dazhuqu. The lowermost conglomerates of these units rest unconformably on an eroded surface of Lhasa terrane rocks. This surface locally has considerable relief. Dazhuqu and Qiuwu formations are both characterized by south-dipping strata. They lie in the footwall of a major north-directed thrust fault of regional extent, which places the hanging wall of Xigaze terrane rocks above them.

Clastic detritus within the formations is sourced from all terranes nearby. Clasts include porphyritic volcanic rocks from the Lhasa terrane; gabbro, serpentinite and ultramafics from the Dazhuqu terrane; green and red cherts from the Bainang terrane; and distal continental margin sedimentary rocks from the Indian terrane. Clasts immediately above the basal unconformity are predominantly derived from the Lhasa terrane. The dominant source of detrital clasts exhibits a gradual change up-section from the north (the Lhasa terrane) to the south of the suture zone (the Indian and other nearby terranes) (Aitchison et al. 2002). This indicates that the conglomeratic succession records tectonic, or otherwise, induced changes in relief during the time of its deposition. Lower Cretaceous radiolarians from red chert clasts fingerprint one of the source terranes.

We report the discovery of tuffaceous layers interbedded within the Dazhuqu Formation as a significant result from this study. These pyroclastic deposits are associated with a magmatic suite, which also intrudes the conglomerates. Earlier works have dated these intrusions and used their age as a constraint on the minimum age of the conglomerates along the suture. The discovery of these tuffs within the conglomerates obviously provides a direct constraint on the timing of their deposition and places further constraints on the timing of collision-related events.

\section{References}

Aitchison JC, AM Davis, Badengzhu and H Luo. 2002. New constraints on the India-Asia collision: The Lower Miocene Gangrinboche conglomerates, Yarlung Tsangpo suture zone, SE Tibet. J Asian Earth Sci 21: 253-256 